\title{
PENGARUH DOSIS KOMPOS TANDAN KOSONG KELAPA SAWIT YANG DI PERKAYA ABU BOILER TERHADAP SIFAT KIMIA TANAH ULTISOL, PERTUMBUHAN, PRODUKSI, KADAR HARA DAN LOGAM BERAT PB PADA TANAMAN SAWI (Brassica juncea L.)
}

\section{The Effect of Improved Quality of Oil Palm Empty Fruit Bunch Compost on the Chemical Properties of Ultisol Soil, Growth, Production, Nutrient Content, and Heavy Metals Pb on Mustard Plants (Brassica juncea L.)}

\author{
Sri Mulyani \\ Dosen Program studi Agroteknologi, Fakultas Pertanian, \\ Universitas Islam Riau, Pekanbaru, Riau \\ Email : srimulyani@agr.uir.ac.id \\ [Diterima: Maret 2019; Disetujui: April 2019]
}

\begin{abstract}
The purpose of this study was to study the effect of improved quality of oil palm empty fruit bunch compost on the chemical properties of ultisol soil, growth, production, nutrient content, and heavy metals $\mathrm{Pb}$ in mustard plants. This study was conducted from March 2015 to January 2016. The study was conducted with a single factor experiment with 13 treatments and 3 replications, so that 39 unit experiments were obtained which were placed into a Completely Randomized Design. The treatment consisted of 4 tankos compost, namely tankos compost. The beginning of the composting process was added to boiler ash at 4 dosage levels, namely $0 \%$ (K1), 15\% (K2), 25\% (K3), 35\% (K4), then given into the soil with 3 dose levels, namely 10 tons/ha (D1), 20 tons/ha (D2), 30 tons/ha (D3). Observational data was analyzed statistically using the Analysis of Variance (ANOVA) with the F test at an alpha level of 5\%. If the treatment is found a significant effect, it will be continued with the Duncan Multiple Range Test (DMRT) at the alpha level of 5\%. The results showed that the various doses of oil palm empty fruit bunch compost plus added boiler ash at the beginning of the composting process at the same dose had a significant effect on increasing Ca-dd, Mg-dd, K-dd soils and decreasing Al-dd soils, plant height, number of leaves, leaf width and $\mathrm{K}$ content of mustard plants. The best dose that can produce the highest production was the composting process treatment that was added with $15 \%$ boiler ash at a dose of 10 tons/ha (K1D1). In the Pb heavy metal content was not measurable, so the plant was suitable for consumption.
\end{abstract}

Keywords: Tankos compost, Ultisol, Boiler ash

\begin{abstract}
ABSTRAK
Tujuan penelitian ini adalah mempelajari pengaruh pemberian kompos tandan kosong kelapa sawit yang telah diperbaiki kualitasnya terhadap sifat kimia tanah ultisol, pertumbuhan, produksi, kadar hara dan logam berat $\mathrm{Pb}$ pada tanaman sawi. Penelitian ini dilaksanakan mulai bulan Maret 2015 samapi dengan Januari 2016. Penelitian ini merupakan percobaan faktor tunggal dengan 13 perlakuan dan 3 ulangan sehingga diperoleh 39 satuan percobaan yang ditempatkan dalam Rancangan Acak Lengkap. Perlakuan terdiri dari 4 kompos tankos, yaitu kompos tankos yang pada awal proses pengomposan ditambahkan dengan abu boiler pada 4 tingkat dosis, yaitu $0 \%(\mathrm{~K} 1), 15 \%(\mathrm{~K} 2), 25 \%(\mathrm{~K} 3), 35 \%(\mathrm{~K} 4)$, kemudian diberikan ke tanah dengan dengan 3 tingkat dosis, yaitu 10 ton/ha (D1), 20 ton/ha (D2), 30 ton/ha (D3). Data pengamatan dianalisis secara statistika menggunakan Analisys of Variance (ANOVA) dengan uji F pada taraf alfa 5\%. Jika perlakuan berpengaruh nyata dilanjutkan dengan uji lanjutan Duncan Multiple Range Test (DMRT) pada taraf alfa 5\%. Hasil Penelitian menunjukkan bahwa pemberian berbagai dosis kompos tandan kosong kelapa sawit yang ditambah abu boiler pada awal proses pengomposan pada dosis yang sama memberikan pengaruh nyata terhadap peningkatan $\mathrm{Ca}-\mathrm{dd}, \mathrm{Mg}-\mathrm{dd}$, $\mathrm{K}-\mathrm{dd}$ tanah dan penurunan $\mathrm{Al}-\mathrm{dd}$ tanah, tinggi
\end{abstract}


tanaman, jumlah daun, lebar daun serta kandungan $\mathrm{K}$ tanaman sawi. Dosis terbaik yang mampu menghasilkan produksi tertinggi adalah pada perlakuan proses pengomposan ditambahkan dengan abu boiler $15 \%$ dengan dosis 10 ton/ha (K1D1). Pada tanaman kandungan logam berat Pb tidak terukur, sehingga tanaman layak untuk dikonsumsi.

Kata kunci: Kompos tankos, Ultisol, Abu boiler

\section{PENDAHULUAN}

Tandan kosong kelapa sawit mengandung hara makro dan mikro lengkap, yaitu: C-organik 58,04\%, N-total $0,79 \%, \mathrm{P}$ -

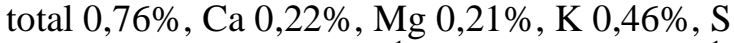
0,03\%, Fe 25,00 mg. $\mathrm{kg}^{-1}$, Mn 99,14 mg.kg-1, Cu 6,81 mg.kg ${ }^{-1}$, Zn 20,15 mg. $\mathrm{kg}^{-1}$, dan logam berat As 2,28 mg.kg ${ }^{-1}$, Hg 0,16 mg. $\mathrm{kg}^{-1}, \mathrm{Cd}$ 3,13 mg.kg ${ }^{-1}, \quad \mathrm{~Pb} 22,83$ mg.kg ${ }^{-1}, \quad \mathrm{Cr} 1,37$ mg. $\mathrm{kg}^{-1}$. Walaupun, tandan kosong kelapa sawit memiliki kandungan hara makro dan mikro lengkap, namun untuk menghasilkan kompos tandan kosong kelapa sawit dengan kualitas yang lebih baik, maka perlu dilakukan perbaikan kualitas. Upaya yang dapat dilakukan adalah dengan menambahkan bahan lain yang merupakan limbah yang berasal dari Pabrik Kelapa Sawit (PKS). Salah satu limbah PKS yang memiliki kandungan hara yang lengkap dan lebih tinggi daripada tandan kosong kelapa sawit adalah abu boiler. Sesuai yang dikemukakan oleh Abner et al. (2010), bahwa kualitas kompos dapat ditingkatkan dengan cara menambahkan abu boiler pada pembuatan kompos limbah pabrik kelapa sawit.

Abu boiler merupakan limbah yang dihasilkan dari sisa pembakaran cangkang dan serat buah kelapa sawit. Jumlah limbah abu boiler yang dihasilkan $\pm 5 \%$ dari jumlah bahan yang dibakar (Borhan et al. 2010). Total limbah abu boiler yang dihasilkan dari pembakaran 33,94 juta ton limbah kelapa sawit, yang terdiri atas 10,84 juta ton cangkang dan 23,10 juta ton serat, diperkirakan menghasilkan limbah abu boiler $\pm 1,70$ juta ton. Abu boiler mengandung hara makro dan mikro yaitu: C-organik 6,61\%, N-total $0,30 \%$, P-total 1,01\%, Ca 2,16\%, Mg 0,55\%, K 1,14\%, S $0,05 \%$, Si $80,09 \%$, Fe 22.100 mg.kg ${ }^{-1}$, Mn 0,69 mg. $\mathrm{kg}^{-1}, \mathrm{Cu} 469,79$ mg.kg- ${ }^{-1}$ Zn 36,28 mg. $\mathrm{kg}^{-1}$, dan logam berat As 4,45 mg.kg-1 $\mathrm{Hg}$ 0,21 mg.kg-1 ${ }^{-1}$ Cd 3,33 mg.kg ${ }^{-1}, \quad \mathrm{~Pb} 29,25$ mg.kg ${ }^{-1}, \mathrm{Cr} 4,61 \mathrm{mg} \cdot \mathrm{kg}^{-1}$. Berdasarkan hasil analisis hara dan logam berat serta potensi dari abu boiler, maka abu boiler dapat dimanfaatkan sebagai bahan tambahan untuk meningkatkan kualitas kompos tandan kosong kelapa sawit.

Jenis tanah yang digunakan dalam penelitian ini adalah tanah Ultisol. Tanah Ultisol memiliki potensi sebagai lahan pertanian yang sangat tinggi dengan luas 48,3 juta hektar yaitu sekitar $29,7 \%$ dari luas daratan Indonesia (Hakim et al. 1986). Namun, kendala sebagai lahan pertanian adalah tingkat kemasaman, kejenuhan $\mathrm{Al}$ yang tinggi, kandungan hara dan bahan organik rendah (Hardjowigeno, 2003). Pemberian kompos tandan kosong kelapa sawit yang telah diperbaiki kualitasnya diharapkan dapat memperbaiki kesuburan tanah Ultisol. Tanaman sawi digunakan sebagai tanaman indikator untuk mempelajari pengaruh pemberian kompos tandan kosong kelapa sawit yang telah diperbaiki kualitasnya terhadap pertumbuhan, produksi, kadar hara dan logam berat $\mathrm{Pb}$ pada tanaman. Berdasarkan beberapa uraian tersebut, maka tujuan yang ingin dicapai pada penelitian ini adalah mempelajari pengaruh pemberian kompos tandan kosong kelapa sawit yang telah diperbaiki kualitasnya terhadap sifat kimia tanah ultisol, pertumbuhan, produksi, kadar hara dan logam berat $\mathrm{Pb}$ pada tanaman sawi.

\section{BAHAN DAN METODE}

Penelitian ini dilaksanakan di rumah kaca, kebun percobaan Cikabayan, IPB. dan analisis sifat kimia tanah dan kadar hara dan logam berat tanah dan tanaman dilakukan di Laboratorium Departemen Ilmu Tanah dan Sumberdaya Lahan, IPB dan Laboratorium Balai Penelitian Tanah, Balai Besar Litbang Sumberdaya Lahan Pertanian (BBSDLP). Penelitian ini 
dilaksanakan mulai bulan Maret 2015Januari 2016.

Alat yang digunakan dalam penelitian ini adalah alat-alat untuk proses pengomposan, alat-alat untuk proses pengamatan, alat-alat laboratoriun untuk analisis, serta alat-alat untuk penanaman sawi. Bahan yang digunakan dalam penelitian ini, adalah 1) limbah tandan kosong kelapa sawit, abu boiler dan limbah cair pabrik yang dihasilkan dari kegiatan pengolahan TBS pabrik pengolahan kelapa sawit PTPN VIII Kertajaya, Kecamatan Malingping, Banten; 2) tanah Ultisol dari Desa Gajrug, Kecamatan Cipanas, Banten; 3) benih sawi ; 4) Pupuk urea, SP-36, dan $\mathrm{KCl}$; 5) Gula merah; 6) Air bebas ion; dan 7) bahan kimia yang diperlukan untuk analisis di laboratorium.

Percobaan pot rumah kaca ini merupakan percobaan faktor tunggal dengan 13 perlakuan dan tiga ulangan sehingga diperoleh 39 satuan percobaan yang ditempatkan dalam Rancangan Acak Lengkap. Penelitian ini menggunakan empat kompos tankos, yaitu kompos tankos yang pada awal proses pengomposan ditambahkan dengan abu boiler pada empat tingkat dosis, yaitu $0 \%$ (K1), $15 \%$ (K2), $25 \%$ (K3), 35\% (K4), kemudian diberikan ke tanah dengan dengan 4 tingkat dosis, yaitu 10 ton/ha (D1), 20 ton/ha (D2), 30 ton/ha (D3). Tanah untuk media tanam ditimbang sebanyak $2.9 \mathrm{~kg}$ BKM setara dengan 3.5 $\mathrm{kg}$ BKU. Tanah yang diberi perlakuan kemudian diinkubasi selama 14 hari. Setelah 14 hari dilakukan inkubasi kembali dengan menggunakan kapur dolomit selama 7 hari dengan pemberian sebanyak 1 Al-dd tanah. Pemberian pupuk urea, SP$36, \mathrm{KCl}$ diberikan dengan dosis $50 \%$ dari standar rekomendasi pemupukan tanaman sawi (100 kg Urea/ha, $100 \mathrm{~kg} / \mathrm{ha}$ SP-36 dan $75 \mathrm{~kg} / \mathrm{ha} \mathrm{KCl}$ ) (Manulu, 2008). Setiap pot ditanami dengan 4 benih yang dipelihara sampai panen. Pemeliharaan yang dilakukan meliputi penyiraman yang dilakukan setiap hari sekali dan diusahakan kadar air tetap pada kondisi kapasitas lapang. Pemanenan dilakukan pada saat tanaman berumur 45 hari setelah tanam.

Tabel 1. Parameter dan metode analisis sifat kimia tanah, kadar hara bagian atas tanaman (pucuk) dan logam berat tanah dan tanaman.

\begin{tabular}{ll}
\hline \multicolumn{1}{c}{ Parameter } & \multicolumn{1}{c}{ Metode analisis/Alat ukur } \\
\hline$\underline{\mathrm{Tanah}}$ & \\
$\mathrm{pH} \mathrm{H}_{2} \mathrm{O}$ & Elektroda (pH meter) \\
$\mathrm{N}$ total & Kjeldahl (Titrasi) \\
$\mathrm{P}$ tersedia & Bray I (Spectrophotometer) \\
$\mathrm{KTK}$ & $\mathrm{NH}_{4} \mathrm{OAc} 1 \mathrm{~N} \mathrm{pH} \mathrm{7.0} \mathrm{(Titrasi)}$ \\
$\mathrm{K}_{\mathrm{dd}}$ & $\mathrm{NH}_{4} \mathrm{OAc} 1 \mathrm{~N} \mathrm{pH} \mathrm{7.0} \mathrm{(Flamephotometer)}$ \\
$\mathrm{Ca}_{\mathrm{dd}}$ dan $\mathrm{Mg}_{\mathrm{dd}}$ & $\mathrm{NH}_{4} \mathrm{OAc} 1 \mathrm{~N} \mathrm{pH} \mathrm{7.0} \mathrm{(AAS)}$ \\
$\mathrm{Al}_{\mathrm{dd}}$ dan $\mathrm{H}_{\mathrm{dd}}$ & $\mathrm{KCl}_{1} \mathrm{~N}$ (Titrasi) \\
Logam berat Pb tersedia tanah & Ekstraksi DTPA (AAS) \\
& \\
Tanaman & \\
$\mathrm{N}$ & $\mathrm{Kjeldahl} \mathrm{(Titrasi)}$ \\
$\mathrm{P}$ & Pengabuan basah (Spectrophotometer) \\
$\mathrm{K}$ & Pengabuan basah (Flamephotometer) \\
$\mathrm{Ca}, \mathrm{Mg}$, dan logam berat $\mathrm{Pb}$ & Pengabuan basah (AAS) \\
Logam berat Pb akar dan tanaman & Oksidasi basah dengan $\mathrm{HNO}_{3}$ dan $\mathrm{HClO}_{4}$ (AAS) \\
\hline
\end{tabular}


Variabel yang diamati dari tanaman sawi adalah (1) tinggi tanaman, jumlah daun, dan lebar daun, pengamatan dilakukan setiap satu minggu sekali yang dimulai pada minggu ke-2 setelah tanam, (2) Berat basah, pengamatan dilakukan setelah panen, (3) Kadar N, P, K, Ca dan Mg pada tanaman, (4) Kadar logam berat $\mathrm{Pb}$ pada tanah, akar dan tanaman. Metode analisis Kadar N, P, K, Ca dan Mg pada tanaman dan logam berat $\mathrm{Pb}$ pada akar dan tanaman disajikan dalam Tabel 1. Data pengamatan dianalisis secara statistika menggunakan Analisys of Variance (ANOVA) dengan uji F pada taraf alfa 5\%. Jika perlakuan berpengaruh nyata dilanjutkan dengan uji lanjutan Duncan Multiple Range Test (DMRT) pada taraf alfa $5 \%$.

Tabel 2. Rata-rata kandungan $\mathrm{pH} \mathrm{H}_{2} \mathrm{O}, \mathrm{P}_{2} \mathrm{O}_{5}$, Al-dd dan $\mathrm{H}$-dd tanah setelah inkubasi dengan berbagai dosis kompos tandan kosong kelapa sawit dan dolomit

\begin{tabular}{ccccc}
\hline Perlakuan & $\mathrm{pH} \mathrm{H}_{2} \mathrm{O}$ & $\mathrm{P}_{2} \mathrm{O}_{5}$ Bray $\left(\mathrm{mg}^{\left.-\mathrm{kg}^{-1}\right)}\right.$ & $\mathrm{Al}-\mathrm{dd}\left(\mathrm{mg} \cdot 100 \mathrm{~g}^{-1}\right)$ & $\mathrm{H}-\mathrm{dd}\left(\mathrm{mg} \cdot 100 \mathrm{~g}^{-1}\right)$ \\
\hline K0D0 & 5,42 & 22,08 & $0,45 \mathrm{~b}$ & 0,27 \\
K1D1 & 5,43 & 22,36 & $0,45 \mathrm{~b}$ & 0,20 \\
K2D1 & 5,45 & 23,04 & $0,38 \mathrm{ab}$ & 0,20 \\
K3D1 & 5,52 & 24,20 & $0,37 \mathrm{ab}$ & 0,20 \\
K4D1 & 5,61 & 24,99 & $0,30 \mathrm{ab}$ & 0,20 \\
K1D2 & 5,63 & 25,25 & $0,30 \mathrm{ab}$ & 0,20 \\
K2D2 & 5,64 & 25,64 & $0,23 \mathrm{ab}$ & 0,13 \\
K3D2 & 5,64 & 26,37 & $0,23 \mathrm{ab}$ & 0,13 \\
K4D2 & 5,64 & 28,65 & $0,23 \mathrm{ab}$ & 0,13 \\
K1D3 & 5,66 & 28,81 & $0,15 \mathrm{a}$ & 0,07 \\
K2D3 & 5,68 & 29,81 & $0,15 \mathrm{a}$ & 0,07 \\
K3D3 & 5,68 & 36,69 & $0,15 \mathrm{a}$ & 0,07 \\
K4D3 & 5,81 & 31,81 & $0,15 \mathrm{a}$ & 0,07 \\
\hline
\end{tabular}

Angka-angka pada kolom yang sama yang diikuti oleh huruf yang sama tidak berbeda nyata pada taraf alfa $5 \%$ (uji selang berganda Duncan Multiple Range Test)

Tabel 2. menunjukan bahwa Al-dd tanah pada kontrol 0,45 mg. $100 \mathrm{~g}^{-1}$, setelah perlakuan menurun menjadi $0,15 \mathrm{mg} \cdot 100 \mathrm{~g}^{-1}$, besarnya penurunan Al-dd adalah 200\%. Al-dd tanah terendah dicapai pada K1D3, K2D3, K3D3 dan K4D3 yang berbeda nyata dengan perlakukan K1D1 dan K0D0. Penurunan Al-dd terjadi karena adanya penambahan kompos dan kapur dolomit. Kompos tankos mengandung
HASIL DAN PEMBAHASAN

Pengaruh Dosis Kompos Tandan Kosong Kelapa Sawit yang diperkaya Abu Boiler dengan Penambahan Dolomit terhadap Sifat Kimia Tanah Ultisol

Hasil analisis ragam menunjukan bahwa setelah pemberian berbagai dosis kompos tandan kosong kelapa sawit yang ditambah abu boiler pada awal proses pengomposan dan dolomit pada dosis yang sama memberikan pengaruh nyata terhadap peningkatan $\mathrm{Ca}-\mathrm{dd}$, Mg-dd, K-dd tanah dan penurunan Al-dd tanah. Namun, tidak berpengaruh nyata terhadap peningkatan $\mathrm{pH} \quad \mathrm{H}_{2} \mathrm{O}, \mathrm{P}_{2} \mathrm{O}_{5}$, dan penurunan $\mathrm{H}$-dd tanah. Walaupun tidak berpengaruh nyata, namun pemberian kompos tandan kosong kelapa sawit yang diperkaya abu boiler dengan penambahan dolomit cenderung meningkatkan nilai $\mathrm{pH} \mathrm{H}_{2} \mathrm{O}, \mathrm{P}_{2} \mathrm{O}_{5}$ dan menurunkan kandungan $\mathrm{H}-\mathrm{dd}$ tanah (Tabel 2). 
kapur dolomit. Menurut Kussuw (1971) netralisasi $\mathrm{Al}$ oleh bahan kapur dimulai ketika ion karbonat bereaksi dengan air membentuk asam karbonat dan ion hidroksil menyebabkan $\mathrm{pH}$ larutan naik, kemudian ion-ion $\mathrm{OH}$ bereaksi dengan $\mathrm{Al}^{3+}$ membentuk $\mathrm{Al}(\mathrm{OH})_{3}$, kemudian $\mathrm{Ca}^{2+}$ dan $\mathrm{Mg}^{2+}$ dari bahan kapur segera menempati kompleks jerapan yang tadinya ditempati oleh aluminium. Persamaan netralisasinya sebagai berikut :

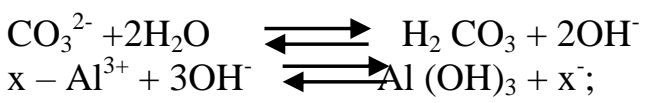

$\mathrm{x}$ adalah kompleks pertukaran

Tabel 3. menunjukan bahwa kandungan Ca-dd tanah pada kontrol $19,11 \mathrm{mg} \cdot 100 \mathrm{~g}^{-1}$ termasuk dalam kategori tinggi, setelah perlakuan meningkat menjadi $22,61 \mathrm{mg} \cdot 100 \mathrm{~g}^{-}$ ${ }^{1}$ termasuk dalam kategori sangat tinggi. Kandungan Mg-dd tanah pada kontrol 10,22 mg. $100 \mathrm{~g}^{-1}$, setelah perlakuan meningkat menjadi $15,27 \mathrm{mg} \cdot 100 \mathrm{~g}^{-1}$ termasuk dalam kategori sangat tinggi. Kadar K-dd tanah pada control $0,46 \quad \mathrm{mg} \cdot 100 \mathrm{~g}^{-1}$ termasuk dalam kategori sedang, setelah perlakuan meningkat menjadi 0,90 mg. $100 \mathrm{~g}^{-1}$ termasuk dalam kategori tinggi (Balai penelitian tanah, 2009). Peningkatan kandungan Ca-dd dan Mg-dd karena adanya sumbangan $\mathrm{Ca}$ dan $\mathrm{Mg}$ yang berasal dari kapur dolomit. Sedangkan kadar K-dd pada tanah setelah ditambah dengan dolomit masih tetap mengalami peningkatan. Hal ini disebabkan karena dari hasil analisis KTK tanah menunjukkan bahwa tanah Ultisol termasuk dalam kategori sangat tinggi, sehingga dengan KTK tanah yang sangat tinggi peningkatan $\mathrm{Ca}$-dd dan $\mathrm{Mg}$-dd tidak menyebabkan K-dd menurun sesuai dengan hasil penelitian Subiksa et al. (2006) menyatakan bahwa KTK tanah yang cukup tinggi, peningkatan $\mathrm{Ca}$-dd dan $\mathrm{Mg}$-dd tidak diikuti dengan penurunan K-dd. Ca-dd tertinggi dicapai pada perlakuan K4D3 yang berbeda nyata dengan perlakuan K3D1, K2D1, K1D1 dan K0D0. Kandungan Mg-dd tertinggi pada perlakuan KAD3 dan berbeda nyata dengan perlakuan K1D2, K4D1, K3D1, K2D1, K1D1 dan K0D0. Sedangkan kandungan K-dd tanah tertinggi pada perlakuan K3D3 yang berbeda nyata dengan perlakuan lainnya.

Tabel 3.Kandungan Ca-dd, Mg-dd dan K-dd tanah pada pemberian berbagai dosis kompos tandan kosong kelapa sawit dan dolomit

\begin{tabular}{ccccc}
\hline Perlakuan & Ca-dd $\left(\mathrm{mg} \cdot 100 \mathrm{~g}^{-1}\right)$ & Mg-dd $\left(\mathrm{mg} \cdot 100 \mathrm{~g}^{-1}\right)$ & K-dd $\left(\mathrm{mg} \cdot 100 \mathrm{~g}^{-1}\right)$ & KTK Tanah $_{\left(\mathrm{mg} \cdot 100 \mathrm{~g}^{-1}\right)}$ \\
\hline K0D0 & $19,11 \mathrm{e}$ & $10,22 \mathrm{~d}$ & $0,46 \mathrm{~g}$ & 41,22 \\
K1D1 & $19,64 \mathrm{de}$ & $10,31 \mathrm{~d}$ & $0,58 \mathrm{f}$ & 42,15 \\
K2D1 & $20,25 \mathrm{cde}$ & $11,29 \mathrm{~cd}$ & $0,59 \mathrm{f}$ & 42,36 \\
K3D1 & $20,65 \mathrm{bcde}$ & $11,29 \mathrm{~cd}$ & $0,59 \mathrm{f}$ & 42,25 \\
K4D1 & $20,92 \mathrm{abcde}$ & $11,45 \mathrm{bcd}$ & $0,60 \mathrm{f}$ & 42,47 \\
K1D2 & $20,91 \mathrm{abcde}$ & $11,72 \mathrm{bcd}$ & $0,73 \mathrm{e}$ & 43,10 \\
K2D2 & $20,98 \mathrm{abcd}$ & $12,97 \mathrm{abc}$ & $0,74 \mathrm{e}$ & 43,62 \\
K3D2 & $21,07 \mathrm{abcd}$ & $13,60 \mathrm{abc}$ & $0,74 \mathrm{e}$ & 43,90 \\
K4D2 & $21,40 \mathrm{abcd}$ & $13,74 \mathrm{ab}$ & $0,80 \mathrm{~d}$ & 43,91 \\
K1D3 & $21,50 \mathrm{abcd}$ & $14,35 \mathrm{a}$ & $0,82 \mathrm{~cd}$ & 44,35 \\
K2D3 & $21,97 \mathrm{abc}$ & $14,35 \mathrm{a}$ & $0,85 \mathrm{c}$ & 44,35 \\
K3D3 & $22,26 \mathrm{ab}$ & $15,26 \mathrm{a}$ & $0,96 \mathrm{a}$ & 44,70 \\
K4D3 & $22,61 \mathrm{a}$ & $15,27 \mathrm{a}$ & $0,90 \mathrm{~b}$ & 45,78 \\
\hline
\end{tabular}

Angka-angka pada kolom yang sama yang diikuti oleh huruf yang sama tidak berbeda nyata pada taraf alfa $5 \%$ (uji selang berganda Duncan Multiple Range Test)

\author{
Pengaruh Dosis Kompos Tandan Kosong \\ Kelapa Sawit yang diperkaya Abu Boiler \\ dengan Penambahan Dolomit terhadap \\ Pertumbuhan Vegetatif Tanaman Sawi
}

Respon dari pemberian berbagai dosis kompos tandan kosong kelapa sawit yang telah diperbaiki kualitasnya terhadap pertumbuhan tanaman dilakukan dengan mengevaluasi 
pertumbuhan yang meliputi tinggi tanaman, jumlah daun, lebar daun. Berdasarkan hasil analisis ragam perlakuan berbagai dosis kompos tandan kosong kelapa sawit yang telah diperbaiki kualitasnya berpengaruh nyata terhadap tinggi tanaman, jumlah daun, dan lebar daun tanaman sawi.

Pada Tabel 4 menunjukan pemberian berbagai dosis kompos tandan kosong kelapa sawit yang telah diperbaiki kualitasnya pada perlakuan K4D2 memberikan nilai tertinggi pada tinggi tanaman sawi yang berbeda nyata dengan perlakuan K1D1 dan K0D0. Pada perlakuan K3D1, K4D1 dan K3D3 memberikan nilai tertinggi pada lebar daun yang berbeda nyata dengan perlakuan K0D0. Pada perlakuan K3D2 dan K4D3 memberikan nilai tertinggi pada jumlah daun yang berbeda nyata dengan perlakuan D0K0. Hal ini disebabkan karena secara umum lebih tingginya kandungan unsur hara pada kompos K3 dan kompos K4 dibandingkan kompos K1 dan kompos K2 (Mulyani, 2016). Selain itu, perbaikan pertumbuhan dan produksi tanaman sawi berkaitan dengan adanya peningkatan kadar hara tanah. Peningkatan tinggi tanaman sawi sebesar $18 \%$, jumlah daun sebesar $30 \%$, lebar daun sebesar $40 \%$ dibandingkan dengan tanaman kontrol.

Tabel 4. Pertumbuhan tanaman sawi pada pemberian berbagai dosis kompos tandan kosong kelapa sawit umur 45 HST

\begin{tabular}{cccc}
\hline Perlakuan & Tinggi tanaman $(\mathrm{cm})$ & Jumlah daun (helai) & Lebar daun $(\mathrm{cm})$ \\
\hline K0D0 & $29,24 \mathrm{c}$ & $10 \mathrm{c}$ & $6,4 \mathrm{~b}$ \\
K1D1 & $31,11 \mathrm{bc}$ & $11 \mathrm{bc}$ & $7,9 \mathrm{a}$ \\
K2D1 & $30,90 \mathrm{bc}$ & $12 \mathrm{ab}$ & $7,7 \mathrm{ab}$ \\
K3D1 & $33,18 \mathrm{ab}$ & $12 \mathrm{ab}$ & $9,2 \mathrm{a}$ \\
K4D1 & $33,00 \mathrm{ab}$ & $12 \mathrm{ab}$ & $9,2 \mathrm{a}$ \\
K1D2 & $31,95 \mathrm{abc}$ & $12 \mathrm{ab}$ & $7,9 \mathrm{a}$ \\
K2D2 & $32,74 \mathrm{ab}$ & $12 \mathrm{ab}$ & $8,1 \mathrm{a}$ \\
K3D2 & $33,68 \mathrm{ab}$ & $13 \mathrm{a}$ & $8,1 \mathrm{a}$ \\
K4D2 & $34,61 \mathrm{a}$ & $12 \mathrm{ab}$ & $8,7 \mathrm{a}$ \\
K1D3 & $32,99 \mathrm{ab}$ & $12 \mathrm{ab}$ & $7,7 \mathrm{ab}$ \\
K2D3 & $33,24 \mathrm{ab}$ & $12 \mathrm{ab}$ & $8,5 \mathrm{a}$ \\
K3D3 & $33,81 \mathrm{ab}$ & $12 \mathrm{ab}$ & $9,2 \mathrm{a}$ \\
K4D3 & $33,59 \mathrm{ab}$ & $13 \mathrm{a}$ & $8,7 \mathrm{a}$ \\
\hline
\end{tabular}

Angka-angka pada kolom yang sama yang diikuti oleh huruf yang sama tidak berbeda nyata pada taraf alfa $5 \%$ (uji selang berganda Duncan Multiple Range Test)

Perbaikan pertumbuhan tanaman sawi akibat penambahan kompos tandan kosong kelapa sawit yang telah diperbaiki kualitasnya berkaitan dengan peningkatan $\mathrm{pH}, \mathrm{C}$ organik, kandungan hara makro tanah. Peningkatan $\mathrm{pH}$ tanah berkaitan dengan semakin tingginya nilai $\mathrm{pH}$ dan kandungan hara $\mathrm{Ca}, \mathrm{Mg}$, dan $\mathrm{K}$ kompos tandan kosong kelapa sawit yang diberikan ke tanah. Peningkatan $\mathrm{pH}, \mathrm{Ca}, \mathrm{Mg}$ dan $\mathrm{K}$ pada tanah dapat menetralkan ion $\mathrm{H}$ sehingga dapat meningkatkan $\mathrm{pH}$ tanah. Peningkatan $\mathrm{pH}$ tanah dapat menurunkan Aldd dan H-dd tanah (Tabel 2) yang dapat menyebabkan racun bagi tanaman. Seiring dengan menurunnya Al-dd dan $\mathrm{H}$-dd tanah meningkatkan kandungan $\mathrm{P}$ tersedia (Tabel 2). Semakin tingginya ketersediaan unsur hara di dalam tanah, maka semakin banyak unsur hara yang diserap tanaman (Tabel 6) sehingga dapat memberikan peningkatkan pada tinggi tanaman, jumlah daun, luas daun.

Pengaruh Dosis Kompos Tandan Kosong Kelapa Sawit yang diperkaya Abu Boiler dengan Penambahan Dolomit terhadap Kandungan Logam Berat $\mathrm{Pb}$ pada Tanah, Akar dan Atas Tanaman (Pucuk) Sawi

Respon dari pemberian berbagai dosis kompos tandan kosong kelapa sawit yang telah diperbaiki kualitasnya terhadap logam $\mathrm{Pb}$ dilakukan dengan melakukan analisis kandungan logam $\mathrm{Pb}$ tersedia tanah, $\mathrm{Pb}$ akar dan bagian atas tanaman (pucuk) sawi. Berdasarkan hasil analisis ragam perlakuan berbagai dosis kompos tandan kosong kelapa sawit yang telah diperbaiki kualitasnya tidak berpengaruh nyata terhadap kandungan logam 
$\mathrm{Pb}$ tersedia tanah dan $\mathrm{Pb}$ akar. Kandungan logam $\mathrm{Pb}$ baik pada tanah maupun akar cenderung mengalami penurunan dengan meningkatnya dosis kompos tandan kosong kelapa sawit yang diberikan ke tanah (Tabel 5).

Kandungan logam $\mathrm{Pb}$ tersedia tanah mengalami penurunan sejalan dengan peningkatan $\mathrm{pH}$ tanah dan adanya peran kadar asam humat yang berasal dari kompos tandan kosong kelapa sawit. Swift (1989) mengemukakan bahwa pada larutan $\mathrm{pH}$ 3,5 sampai 9, asam humat membentuk sistem koloid polielektrolit linier yang bersifat fleksibel, sedangkan pada $\mathrm{pH}$ rendah asam humat berbentuk kaku (rigit) dan cenderung teragregasi membentuk suatu padatan makromolekul melalui ikatan hidrogen. Pada $\mathrm{pH}$ yang meningkat akan menyebabkan ikatan hidrogen semakin lemah sehingga agregat akan terpisah satu sama lain. Keadaan tersebut dipengaruhi oleh asosiasi gugus fungsional yang bersifat asam pada asam humat seperti - $\mathrm{COOH}$. Umumnya gugus -
$\mathrm{COOH}$ terdisosiasi pada $\mathrm{pH}$ sekitar $\mathrm{pH} 4$ sampai 5, sedangkan gugus - $\mathrm{OH}$ fenolat atau$\mathrm{OH}$ alkoholat terdisosiasi pada $\mathrm{pH}$ sekitar 8 sampai 10. Dengan demikian, dapat dinyatakan bahwa pada $\mathrm{pH}$ yang relatif tinggi (konsentrasi $\mathrm{H}^{+}$rendah) akan meningkatkan konsentrasi dari -COO- dan O- yang dapat berfungsi sebagai ligan pada asam humat. Tan (1991) mengemukakan bahwa salah satu jenis logam transisi yaitu $\mathrm{Pb}^{2+}$ kebanyakan ikatan yang terjadi karena ikatan koordinasi dengan ligan organik sehingga ikatan sangat kuat dan sukar digantikan oleh kation-kation $\mathrm{K}, \mathrm{Ca}$ dan $\mathrm{Mg}$.

Data pada Tabel 5 menunjukkan bahwa tanaman sawi mampu mengakumulasikan $\mathrm{Pb}$ pada bagian akar. Menurut Leep (1981), sebagian besar $\mathrm{Pb}$ yang terambil oleh akar secara cepat berubah menjadi bentuk yang tidak aktif melalui proses deposisi dalam akar sehingga sukar ditranslokasikan ke bagianbagian tanaman yang lain.

Tabel 5. Kandungan $\mathrm{Pb}$ pada tanah, akar dan daun tanaman sawi

\begin{tabular}{|c|c|c|c|}
\hline \multirow{3}{*}{ Perlakuan } & \multicolumn{3}{|c|}{ Logam berat $\mathrm{Pb}$} \\
\hline & Tanah & Akar & Atas Tanaman (pucuk) \\
\hline & \multicolumn{3}{|c|}{ - } \\
\hline K0D0 & 0,35 & 3,64 & $\operatorname{tr}$ \\
\hline K1D1 & 0,33 & 3,33 & $\operatorname{tr}$ \\
\hline K2D1 & 0,30 & 2,73 & $\operatorname{tr}$ \\
\hline K3D1 & 0,26 & 2,73 & $\operatorname{tr}$ \\
\hline K4D1 & 0,28 & 2,42 & $\operatorname{tr}$ \\
\hline K1D2 & 0,24 & 2,42 & $\operatorname{tr}$ \\
\hline $\mathrm{K} 2 \mathrm{D} 2$ & 0,22 & 2,12 & $\operatorname{tr}$ \\
\hline $\mathrm{K} 3 \mathrm{D} 2$ & 0,19 & 1,21 & $\operatorname{tr}$ \\
\hline $\mathrm{K} 4 \mathrm{D} 2$ & 0,18 & 0,91 & $\operatorname{tr}$ \\
\hline K1D3 & 0,18 & 0,91 & $\operatorname{tr}$ \\
\hline K2D3 & 0,17 & 0,91 & $\operatorname{tr}$ \\
\hline K3D3 & 0,15 & 0,61 & $\operatorname{tr}$ \\
\hline K4D3 & 0,16 & 0,61 & $\operatorname{tr}$ \\
\hline
\end{tabular}

Keterangan : $\operatorname{tr}=$ tidak terukur

Pada tanaman kandungan logam berat $\mathrm{Pb}$ tidak terukur, dan jika merujuk pada SNI 7387 (2009) tentang batas maksimum cemaran logam berat $\mathrm{Pb}$ dalam pangan, batas maksimum logam berat $\mathrm{Pb}$ yang diperbolehkan adalah 0,5 ppm, Dengan demikian ditinjau dari kandungan logam $\mathrm{Pb}$ pada bagian atas tanaman 
(pucuk), maka tanaman layak untuk dikonsumsi.

Menurut PP No.101 tahun 2014, abu boiler dimasukkan sebagai limbah B3 (Bahan Berbahaya dan Beracun) dari sumber spesifik khusus, akan tetapi disarankan agar abu boiler tidak dimasukkan ke dalam limbah B3, karena abu boiler dapat dimanfaatkan untuk pertanian sebagai bahan peningkat kualitas kompos tandan kosong kelapa sawit. Hasil analisis bagian atas tanaman (pucuk) sawi kandungan logam berat $\mathrm{Pb}$ tidak terukur. Hal ini menunjukkan bahwa keberadaan abu boiler dalam bidang pertanian tidak merusak lingkungan dan aman digunakan untuk budidaya tanaman sawi.

Pengaruh Dosis Kompos Tandan Kosong Kelapa Sawit yang diperkaya Abu Boiler dengan Penambahan Dolomit terhadap Kadar Hara bagian atas tanaman (pucuk)

Pengaruh pemberian berbagai dosis kompos tandan kosong kelapa sawit yang telah diperbaiki kualitasnya terhadap kadar hara bagian atas tanaman (pucuk) pada percobaan pot rumah kaca dengan indikator tanaman sawi disajikan pada Tabel 6. Berdasarkan hasil analisis ragam, perlakuan berbagai dosis kompos tandan kosong kelapa sawit yang telah diperbaiki kualitasnya tidak berpengaruh nyata terhadap kandungan $\mathrm{N}, \mathrm{P}, \mathrm{Ca}$, dan $\mathrm{Mg}$ tanaman, tetapi berpengaruh nyata terhadap kandungan $\mathrm{K}$ tanaman dan berat basah tanaman per pot. Namun, ada kecenderungan kandungan hara $\mathrm{N}, \mathrm{P}, \mathrm{Ca}$ dan $\mathrm{Mg}$ meningkat dengan meningkatnya dosis kompos yang diberikan ke tanah. Secara umum kompos K3 dan kompos K4 merupakan jenis kompos yang terbaik untuk meningkatkan kadar hara bagian atas tanaman (pucuk) dan berat basah tanaman per pot.

Tabel 6. Kadar hara N, P, K, Ca, dan Mg bagian atas tanaman (pucuk) dan berat basah tanaman sawi pada umur $45 \mathrm{HST}$

\begin{tabular}{ccccccc}
\hline Perlakuan & N & P & K & Ca & Mg & $\begin{array}{c}\text { Berat basah tanaman } \\
\text { (g/pot) }\end{array}$ \\
\hline K0D0 & 2,77 & 0,66 & $1,65 \mathrm{~b}$ & 1,63 & 0,54 & $73,4 \mathrm{c}$ \\
K1D1 & 2,78 & 0,83 & $1,83 \mathrm{~b}$ & 1,75 & 0,56 & $109,3 \mathrm{ab}$ \\
K2D1 & 2,75 & 0,80 & $1,83 \mathrm{~b}$ & 1,82 & 0,55 & $105,2 \mathrm{ab}$ \\
K3D1 & 2,83 & 0,87 & $1,86 \mathrm{~b}$ & 1,84 & 0,57 & $111,7 \mathrm{ab}$ \\
K4D1 & 2,85 & 0,89 & $1,91 \mathrm{~b}$ & 1,87 & 0,59 & $107,3 \mathrm{ab}$ \\
K1D2 & 2,95 & 0,94 & $1,92 \mathrm{~b}$ & 1,92 & 0,60 & $96,1 \mathrm{abc}$ \\
K2D2 & 2,98 & 0,94 & $1,95 \mathrm{~b}$ & 1,93 & 0,61 & $114,2 \mathrm{ab}$ \\
K3D2 & 3,04 & 0,94 & $1,97 \mathrm{~b}$ & 1,94 & 0,61 & $115,8 \mathrm{a}$ \\
K4D2 & 3,15 & 1,04 & $2,10 \mathrm{~b}$ & 1,95 & 0,61 & $97,4 \mathrm{abc}$ \\
K1D3 & 3,47 & 1,06 & $2,15 \mathrm{~b}$ & 1,97 & 0,62 & $116,7 \mathrm{a}$ \\
K2D3 & 3,47 & 1,09 & $2,19 \mathrm{~b}$ & 2,08 & 0,63 & $89,0 \mathrm{bc}$ \\
K3D3 & 3,57 & 1,26 & $2,22 \mathrm{~b}$ & 2,26 & 0,66 & $125,1 \mathrm{a}$ \\
K4D3 & 3,54 & 1,25 & $2,74 \mathrm{a}$ & 2,34 & 0,66 & $124,5 \mathrm{a}$ \\
\hline A & & &
\end{tabular}

Angka-angka pada kolom yang sama yang diikuti oleh huruf yang sama tidak berbeda nyata pada taraf alfa $5 \%$ (uji selang berganda Duncan Multiple Range Test)

Tabel 6. menunjukkan bahwa kandungan $\mathrm{K}$ bagian atas tanaman (pucuk) tertinggi terdapat pada perlakuan K4D3 yang berbeda nyata dengan semua perlakuan. Kandungan $\mathrm{K}$ tanaman mengalami peningkatan $66 \%$ dibandingkan dengan kontrol. Hal ini karena ada nya sumbangan kandungan $\mathrm{K}$ dari kompos $\mathrm{K} 4$. Walaupun kadar $\mathrm{K}$ tanaman tertinggi dicapai oleh perlakuan K4D3, namun berat basah tanaman 
tertinggi tidak terdapat pada perlakuan tersebut. Munawar (2011) mengemukakan bahwa fenomena yang menarik terkait dengan kadar hara K, yakni bahwa beberapa jenis tanaman mempunyai kecenderungan untuk menyerap $\mathrm{K}$ lebih banyak daripada yang dibutuhkan pada saat banyak $\mathrm{K}$ tersedia di dalam tanah, tetapi kelebihan tersebut tidak dapat meningkatkan hasil tanaman. Fenomena ini disebut dengan konsumsi berlebih (luxury consumption).

Dosis terbaik yang mampu menghasilkan berat basah tanaman sawi tertinggi adalah pada perlakuan kompos K3 dengan dosis 30 ton/ha (K3D3), dengan peningkatan sebesar $85 \%$ dibandingkan dengan kontrol. Namun, pemberian perlakuan Kompos 1 dengan dosis 10 ton/ha (K1D1) lebih disarankan dari pada pemberian kompos K3 dengan dosis 30 ton/ha (K3D3), karena pada perlakuan K1D1 sudah mampu mencapai berat basah yang tidak berbeda nyata dengan perlakuan K3D3. Keadaan ini memberi petunjuk bahwa pemberian kompos 10 ton/ha lebih ekonomis.

\section{KESIMPULAN}

Berdasarkan data hasil penelitian yang telah dilaksanakan dapat disimpulkan bahwa:

1. Pemberian berbagai dosis kompos tandan kosong kelapa sawit yang ditambah abu boiler pada awal proses pengomposan dan dolomit pada dosis yang sama memberikan pengaruh nyata terhadap peningkatan $\mathrm{Ca}$ dd, Mg-dd, K-dd tanah dan penurunan Aldd tanah. Namun, tidak berpengaruh nyata terhadap peningkatan $\mathrm{pH} \mathrm{H}_{2} \mathrm{O}, \mathrm{P}_{2} \mathrm{O}_{5}$, dan penurun H-dd tanah.

2. Pemberian berbagai dosis kompos tandan kosong kelapa sawit yang telah diperbaiki kualitasnya memberikan pengaruh nyata terhadap tinggi tanaman, jumlah daun, lebar daun serta kandungan $\mathrm{K}$ tanaman sawi. Dosis terbaik yang mampu menghasilkan produksi tertinggi adalah pada perlakuan kompos K1 dengan dosis 10 ton/ha (K1D1).

3. Pada tanaman kandungan logam berat $\mathrm{Pb}$ tidak terukur, sehingga tanaman layak untuk dikonsumsi.

\section{DAFTAR PUSTAKA}

Abner, J. S, Burden JL, Foster AL. 2010. Economic benefits of using aerated bunkers to produce consistent highquality compost from palm oil mill by products. Transforming Oil Palm Industri: Product Development and Process Technology. Proceedings International Oil Palm Conference 2010; Jogja Expo Center, Yogyakarta, Indonesia, 1-3 Juni 2010. IOPC. hlm 251-261.

Balai Penelitian Tanah. 2009. Petunjuk Teknis Analisis Kimia Tanah, Tanaman, Air, dan Pupuk. Balai Penelitian Tanah, Badan Penelitian dan Pengembangan Pertanian, Departemen Pertanian, Bogor.

Borhan MN, Ismail A, Rahmat RA. 2010. Evaluation of palm oil fuel ash on asphalt mixtures. J. Basic \& Appl. Sci. 4(10): 5456-5463.

Hakim N, Nyakpa MY, Lubis AM, Nugroho SG, Diha MA, Hong GB, dan Bailey HH. 1986. Dasar-Dasar Ilmu Tanah. Lampung (ID): Universitas Lampung.

Hardjowigeno S. 2003. Klasifikasi Tanah Dan Pedogenesis. Jakarta (ID): Akademika Pressindo.

Kussow, W. R. 1971. Introduction to Soil Chemistry. Departemen Ilmu Tanah. Fakultas Pertanian. Institut Pertanian Bogor. Bogor.

Leep, N. W. 1981. Effecct Heavy Metal Pollution on Plant. London: Applied Science.

Manulu, D. F. 2008. Pemanfaatan limbah lumpur kering kelapa sawit sebagai sumber bahan organik untuk campuran media tanam sawi (Brassica juncea) [skripsi]. Bogor (ID): Institut Pertanian Bogor.

Mulyani S. 2016. Quality Improvement of Compost from Empty Oil Palm Fruit Bunch by the Addition of Boiler Ash and its Effect on Chemical Properties of Ultisol and the Production of Mustard (Brassica juncea L.). Journal of Tropical Soils, 21(3): 161-169.

Munawar A. 2011. Kesuburan Tanah dan Nutrisi Tanaman. Bogor (ID): IPB Press. 
Subiksa IGM, Adiningsih JS, Sudarsono, dan Sabiham S. 2014. Pengaruh Ameliorasi dan Pemupukan K terhadap Parameter Hubungan Q-I Kalium pada Tanah Mineral Masam. J. Tanah dan Iklim, 22(2): 40-49.

Swift, R. S. 1989. Molecular Weight, Size, Shape, and Charge Characteristics of Humic Substance: Some Basic Considerations. John wiley and Sons. Chichester.

Tan, K. H. 1991. Dasar-Dasar Kimia Tanah. Yogyakarta (ID): Terjemahan Goenadi. 